\title{
Geoinformatics Technology Distributed Geospatial Database Development for Economic Crisis Management and Natural Disasters in Sudan
}

\author{
Dr. Taha Alfadul Taha Ali \\ Geoinformatics Centre, Alzaiem Alazhari University, Khartoum, Sudan \\ Email: Tahapilot13@gmail.com
}

\begin{abstract}
:
Distributing Geodatabase allows organizations to disperse their data as necessary from central servers to regional or local offices, which may be in a connected or disconnected environment. The aim of this study is distributed geospatial database development For Economic Crisis Management and Natural Disasters (ECM-GDB) using Geoinformatics technology. The motivation is deep need to organize the Economic Crisis Management and Natural Disasters in Sudan. The objectives are: Define the crisis \& emergency concepts, Design and implementation Economic Crisis Management and Natural Disasters Geodatabase (ECM-GDB) Geodatabase in Sudan, and apply GIS call center Managing Economic Crises and Natural Disasters the GIS call center.
\end{abstract}

The importances are to support decision maker in Government, Society and Customer. The methodology depends on GIS phases. There are many recommendations of this study: build ECM System. Also There are many future researches: build many mobile applications specific ECM.

Keywords: Geodatabase Replication, Geoinformatics Technology Economic Crisis Management (GTECM), Sustainable development, Environment sector, desktop/web/Mobile application, Geosmart City. 


\section{Introduction}

Distributing Geodatabase allows organizations to disperse their data as necessary from central servers to regional or local offices, which may be in a connected or disconnected environment. This is achieved through replication of the Geodatabase in whole or in part and dispensing these replicas as necessary throughout an organization. As the replicas are updated, changes can be coordinated between the offices through a synchronization process.

Distributing Geodatabase allows organizations to disperse their data as necessary from central servers to regional or local offices, which may be in a connected or disconnected environment. The aim of this study is distributed geospatial database development For Economic Crisis Management and Natural Disasters (ECM-GDB) using Geoinformatics technology. The motivation is deep need to organize the Economic Crisis Management and Natural Disasters in Sudan. The objectives are design Economic Crisis Management and Natural Disasters Geodatabase (ECM-GDB) Geodatabase, Implementation distribution Economic Crisis Management and Natural Disasters (ECM-GDB) in Sudan, and apply GIS call center Managing Economic Crises and Natural Disasters the GIS call center. The objective is to support decision maker in Government, Society and Customer.

GIS-based DSS Data Model Business Tourism in Sudan (Alfadul, 2017): this study discusses to build data model of business tourism using geographic information system, to decision support makers. This study obtained many results Build the Conceptual GIS Model 5A's (Attraction, Accommodation, Access, Amenity, Awareness), and recommended to develop enterprise geospatial database in Sudan. Also there are many research like "modeling a Geo-Spatial Database for Managing Travelers' Demand" (Singh \& Preetvanti, 2014), "Design and Implementation of a User Friendly Geodatabase System for the Texas" (Uppala, 2006), "Database design and development for census mapping in Nigeria" (Akinyemi, 1999). All these researches use the Geodatabase . Also many research related GIS crisis management like THE CRISIS MANAGEMENT USINGGIS (Manouchehr, n.d.), the aim of the paper is using this technology to help for getting the information that needed for planning of crisis management. "The implementation of the GIS tools in crisis management" (Michał, 2017), APPLICATION OF GEOGRAPHIC INFORMATION SYSTEMS IN CRISIS MANAGEMENT (Vasil, 2016), 


\section{Background}

Crisis management is the process by which an organization deals with a disruptive and unexpected event that threatens to harm the organization or its stakeholders (Bundy et al. 2017). The study of crisis management originated with the large-volumes of industrial and environmental disasters in the 1980s (Shrivastava et al. 1988), (ASIS International, 2009). Three elements are common to a crisis: (a) a threat to the organization, (b) the element of surprise, and (c) a short decision time. (eeger, M, 1998) Venette (Venette, 2003), argues that "crisis is a process of transformation where the old system can no longer be maintained". Therefore, the fourth defining quality is the need for change. If change is not needed, the event could more accurately be described as a failure or incident.During the crisis management process, it is important to identify types of crises in that different crises necessitate the use of different crisis management strategies. (Coombs, 1999). Potential crises are enormous, but crises can be clustered (Coombs, 1999), (Lerbinger, 1997) categorized eight types of crises: Natural disaster, Technological crises, Confrontation, Malevolence, Organizational Misdeeds, Workplace Violence, Rumours and Terrorist attacks/man-made disasters.There are many Geodatabase types:file GDB, personal GDB and Multiuser GDB (Desktop, workgroup and ArcSDE/ enterprise GDB).single-user GDB. In Economic Crisis Management and Natural Disasters (ECM-GDB) we should use enterprise Geodatabase.

\section{Table (1): Terms definition}

\begin{tabular}{|c|c|c|}
\hline & Terms & Definitions \\
\hline 1. & Emergency & $\begin{array}{l}\text { An emergency is a deviation from planned or expected behavior } \\
\text { or a course of events that endangers or adversely affects people, } \\
\text { property, or the environment. }\end{array}$ \\
\hline 2. & Disaster & $\begin{array}{l}\text { Disasters are characterized by the scope of an emergency. An } \\
\text { emergency becomes a disaster when it exceeds the capability of } \\
\text { the local resources to manage it. Disasters often result in great } \\
\text { damage, loss, or destruction. }\end{array}$ \\
\hline 3. & Risk & $\begin{array}{l}\text { Risk is the potential or likelihood of an emergency to occur. For } \\
\text { example, the risk of damage to a structure from an earthquake is } \\
\text { high if it is built on or adjacent to an active earthquake fault. The }\end{array}$ \\
\hline
\end{tabular}




\begin{tabular}{|l|l|l|}
\hline & \multicolumn{2}{|c|}{$\begin{array}{l}\text { risk of damage to a structure where no earthquake fault exists is } \\
\text { low. }\end{array}$} \\
\hline 4. & Hazard & $\begin{array}{l}\text { Hazard refers generally to physical characteristics that may cause } \\
\text { an emergency. For example, earthquake faults, active volcanoes, } \\
\text { flood zones, and highly flammable brush fields are all hazards. }\end{array}$ \\
\hline
\end{tabular}

Table 2: Emergency Types

\begin{tabular}{|l|l|l|}
\hline & $\begin{array}{l}\text { Emergencies Types } \\
\text { (Johnson, 2000) }\end{array}$ & Definitions \\
\hline 1. & Natural Disasters & $\begin{array}{l}\text { Natural disasters include those unplanned events that } \\
\text { occur as a result of natural processes such as } \\
\text { earthquakes, tornadoes, tsunami, freezes, blizzards, } \\
\text { extreme heat or cold, drought, or insect infestation. }\end{array}$ \\
\hline 2. & Internal Disturbances & $\begin{array}{l}\text { Internal disturbances are those events or activities } \\
\text { planned by a group or individual to intentionally cause } \\
\text { disruption. This includes riots, demonstrations, } \\
\text { large-scale prison breaks, and violent strikes. }\end{array}$ \\
\hline 3. & $\begin{array}{l}\text { Energy and Material } \\
\text { Shergencies as a result of shortages include strikes, } \\
\text { price wars, and resource scarcity. }\end{array}$ \\
\hline 4. & Attack & $\begin{array}{l}\text { This includes acts of large-scale terrorism or war using } \\
\text { nuclear, conventional, or biological agents. }\end{array}$ \\
\hline
\end{tabular}

Table 3: Emergency management phases

\begin{tabular}{|l|l|l|}
\hline & $\begin{array}{l}\text { Emergency } \\
\text { Management Phases }\end{array}$ & Definitions \\
\hline 1. & Planning & $\begin{array}{l}\text { Activities necessary to analyze and document the possibility } \\
\text { of an emergency or disaster and the potential consequences } \\
\text { or impacts on life, property, and the environment. This } \\
\text { includes assessing the hazards, risks, mitigation, } \\
\text { preparedness, response, and recovery needs. }\end{array}$ \\
\hline
\end{tabular}




\begin{tabular}{|l|l|l|}
\hline Mitigation & $\begin{array}{l}\text { Activities that actually eliminate or reduce the probability } \\
\text { of a disaster (for example, arms buildup to deter enemy } \\
\text { attack, or legislation that requires stringent building codes }\end{array}$ \\
in earthquake prone areas). It also includes long-term \\
activities designed to reduce the effects of unavoidable \\
disaster (for example, land use management, establishing \\
comprehensive emergency management programs such as \\
vegetation clearance in high fire danger areas, or building \\
restrictions in potential flood zones). \\
\hline Preparedness & \begin{tabular}{l} 
Activities necessary to the extent that mitigation measures \\
have not,or cannot, prevent disasters. In the preparedness \\
phase, governments, organizations, and individuals develop \\
plans to save lives and minimize disaster damage (for \\
example, compiling state resource inventories, mounting \\
training exercises, installing early warning systems, and \\
preparing predetermined emergency response forces). \\
Preparedness measures also seek to enhance disaster \\
response operations (for example, by stockpiling vital food \\
and medical supplies, through training exercises, and by \\
mobilizing emergency response personnel on standby). \\
\hline Activities following an emergency or disaster. These \\
activities are designed to provide emergency assistance for \\
victims (for example, search and rescue, emergency shelter, \\
medical care, and mass feeding). They also seek to stabilize \\
the situation and reduce the probability of secondary \\
damage (for example, shutting off contaminated water \\
supply sources, and securing and patrolling areas prone to \\
looting) and to speed recovery operations (for example, \\
damage assessment). \\
Activities necessary to return all systems to normal or
\end{tabular} \\
\hline \multirow{2}{*}{ Response } & & \\
\hline & &
\end{tabular}




\begin{tabular}{|l|l|}
\hline better. They include two sets of activities: (1) short-term \\
recovery activities return vital life support systems to \\
minimum operating standards (for example, cleanup, \\
temporary housing, and access to food and water), and (2) \\
long-term recovery activities may continue for a number of \\
years after a disaster. Their purpose is to return life to \\
normal or improved levels (for example, redevelopment \\
loans, legal assistance, and community planning).
\end{tabular}

\section{Materials and Methods}

\subsection{Study Area:}

The Sudan contains 18 states and 6 sectors, any state contain many crisis economic impact fields.

\subsection{Data Source :}

We should collect descriptive and spatial data and information for Economic Crisis Management and Natural Disasters from all Sudan country.

\subsection{Methods:}

We should use hardware (PC, GPS and Network ...others), Software (GIS software, RS software, .others), People (Manager, Administrators, Governments, Society, Customer), In other side, in methods we should divide the trace of data and information.

\section{Discussion and Result}

Distributed Geospatial Database Development for: We Design Economic Crisis Management and Natural Disasters (ECM-GDB) Geodatabase according Designing and Building a Call Center. 


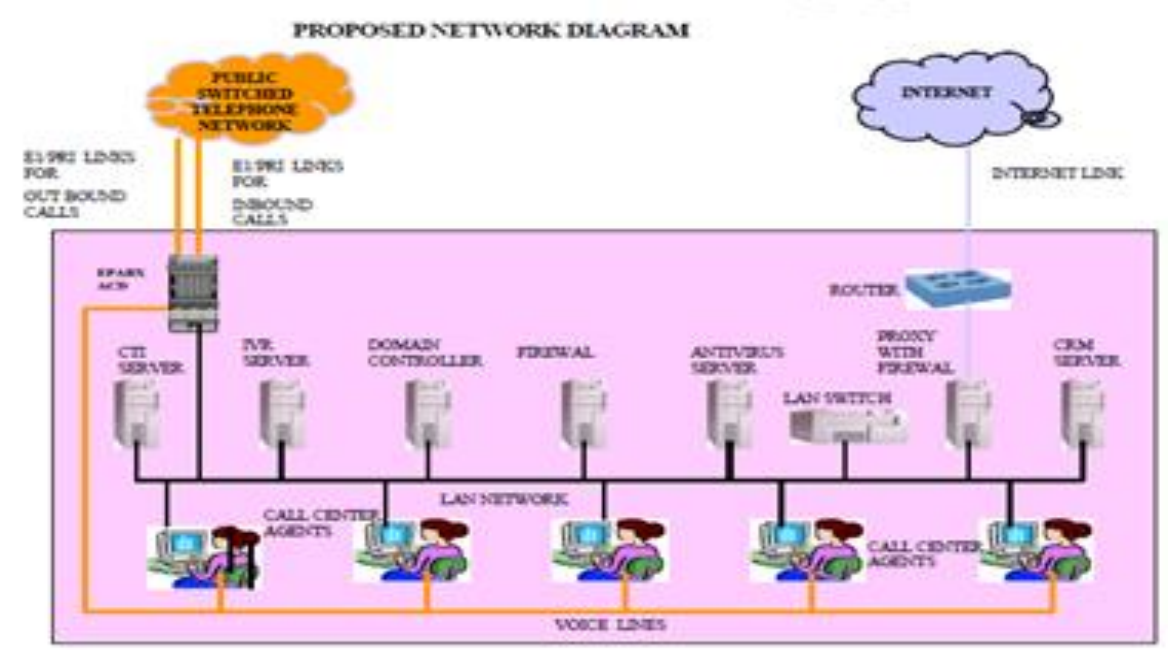

Figure 1: Economic Crisis Management and Natural Disasters (ECM-GDB) network distribution

Distributed Geospatial Database Development for Economic Crisis Management and Natural Disasters (ECM-GDB):Sudan contains 6 Sectors and 18 states: Northern Sector (SN), Khartoum Sector (SKh), Eastern Sector (SE), Center Sector (SR), Kordfan Sector (SR), Darfur Sector (SD).

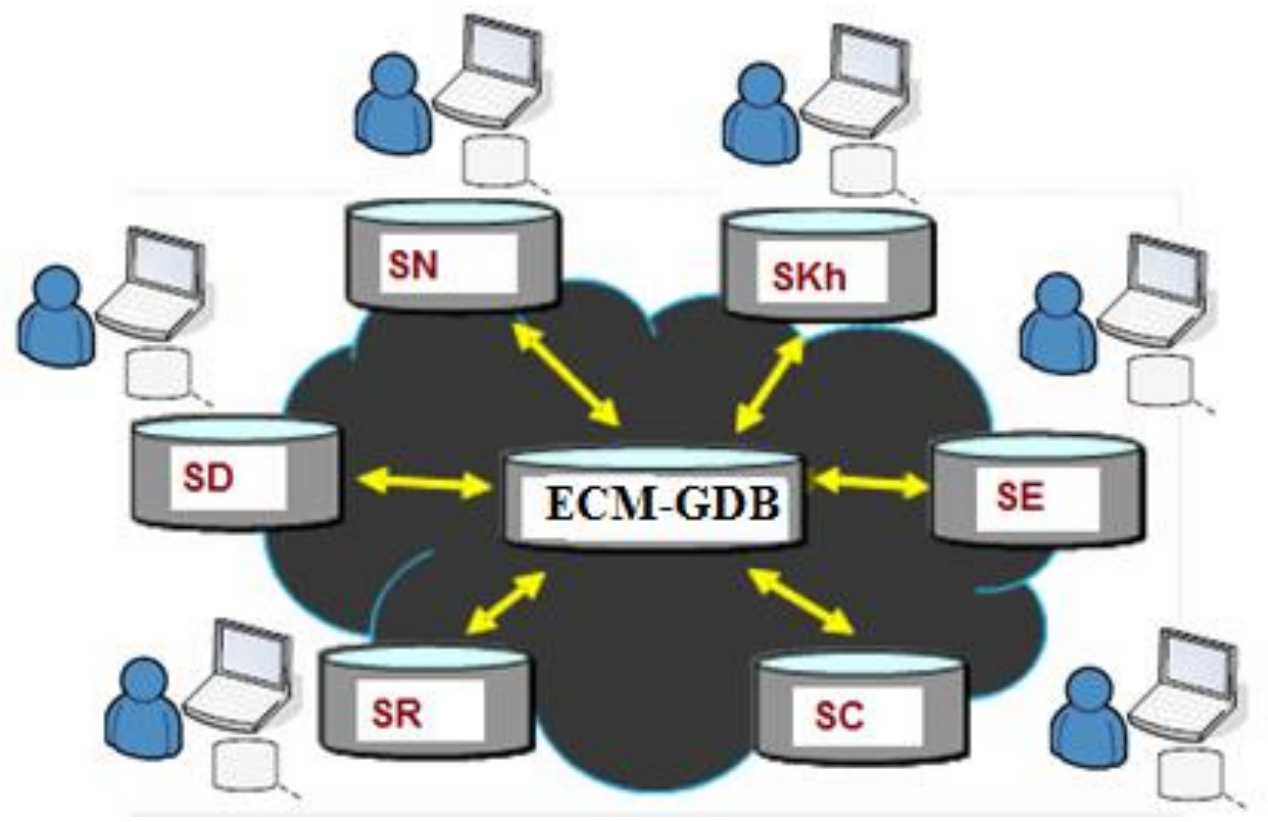

Figure 2: Economic Crisis Management and Natural Disasters (ECM-GDB) 


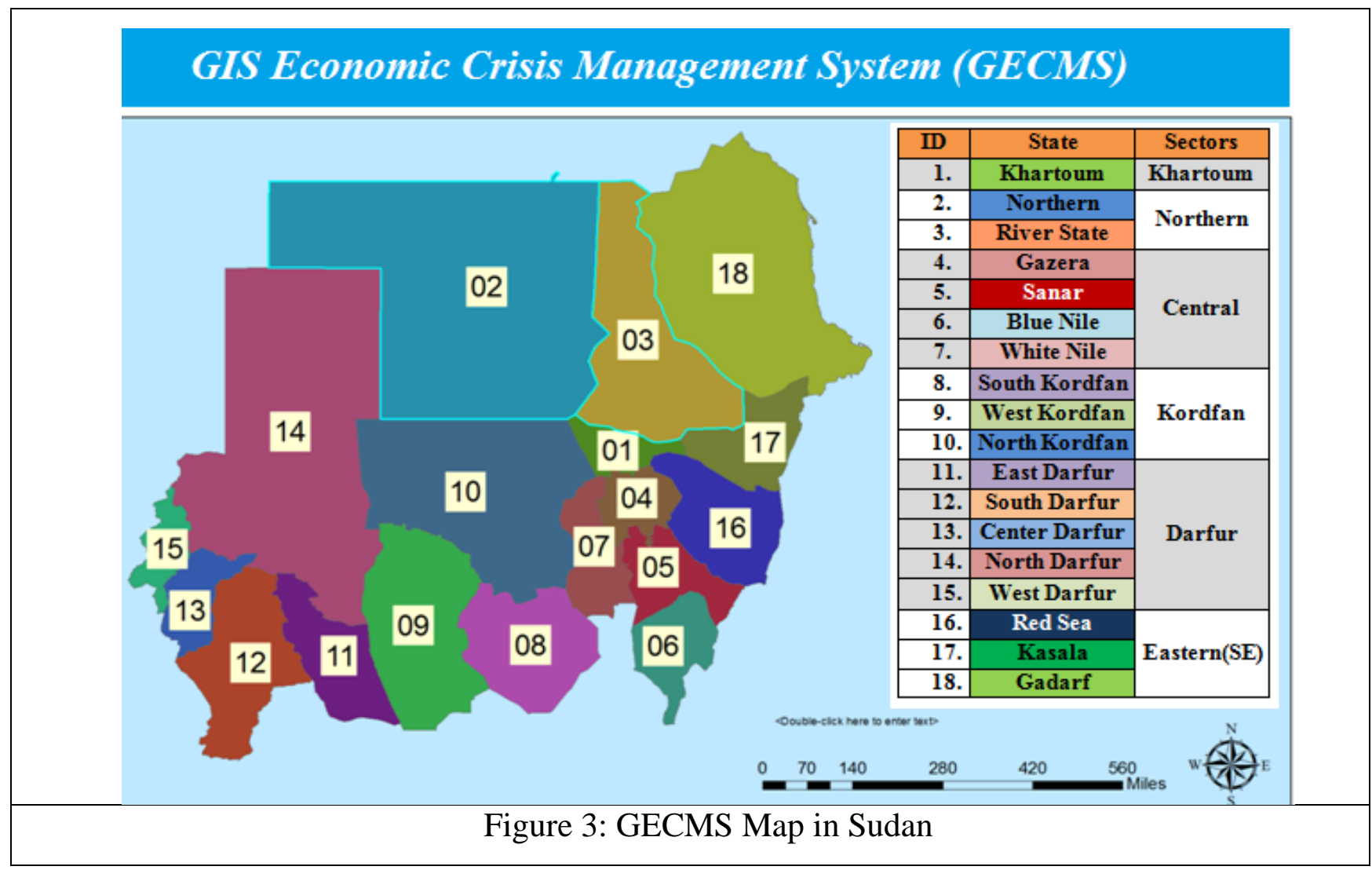

For Distributed Geospatial Database Development for Economic Crisis Management and Natural Disasters (ECM-GDB) in Sudan, We are fragmentation five Geodatabase: Study Area Geodatabase, Economics Geodatabase, Society Geodatabase, Request Geodatabase, and Response Geodatabase. All fragmentation Geodatabase divided at many datasets. A call center is a centralized office used for the purpose of receiving and transmitting a large volume of requests by telephone. Call centers can be a part of or known as: Contact Center, Customer Interaction Center, Customer Service, and Customer Interaction Framework. The main types of call centers: Inbound (Agents receive requests from customers, provide service, and close issues), Outbound and Dispatch centers (Valenzuela, 2008).

According to previous discussions, we build the GECMS Model. and apply GIS call center Managing Economic Crises and Natural Disasters the GIS call center. 


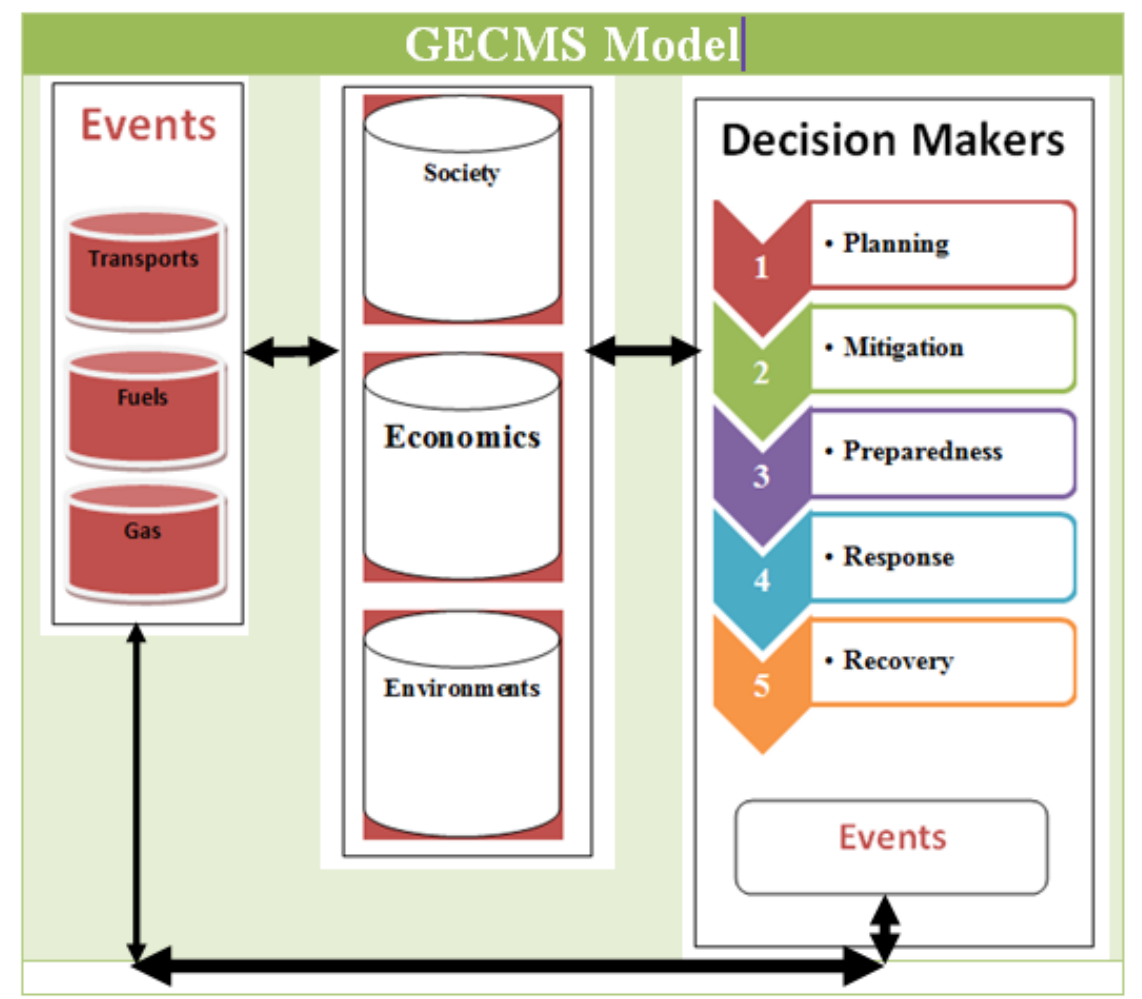

Figure 4 :GECMS Model.

\section{Conclusion}

The study discussed the potential of geospatial technology, and its role in crisis management, disasters or economic emergencies, by building a geographical database for the sectors and states in Sudan, in addition to building a model that clarifies the role of decision makers and their interaction with events and System. There are many future studies in the field to address economic problems in Sudan in the form of an integrated model, using operations management and scheduling applications

\section{References}

Alfadul, Taha (2017). GIS-based DSS Data Model Business Tourism in Sudan, sudanese journal of computing and Geoinformatics, Geoinformatics center, AAU university.

Singh, Sunil and Singh, Preetvanti (2014). Modeling A Geo-Spatial Database For Managing Travelers' Demand, International Journal of Database Management Systems ( IJDMS ) Vol.6, No.2, Department of Physics and Computer Science, Faculty of Science, Dayalbagh Educational Institute (Deemed University) Agra, India. 
Uppala, Abhilash (2006). Design and Implementation of a User Friendly Geodatabase System for the Texas, Master of Science in Computer Science, Faculty of the Department of Computing and Mathematical Sciences Texas A\&M University-Corpus Christi, Texas.

Akinyemi, F. O. (1999) "Database design and development for census mapping in Nigeria", in Balogun, O. Y. \& S. S. O. Soneye, (Eds.): Cartography in the Service of Government, Nigeria, Lagos: Nigerian Cartographic Association, pp. 191-202.

Shaghaghi K. Manouchehr (n.d.),THE CRISIS MANAGEMENT USING GIS, Müszaki Tudományi Kar, Széchenyi István Egyetem, Győr, Magyarország

Michał (2017). The implementation of the GIS tools in crisis management, WSN 72, 211-218, http://www.worldscientificnews.com/

Vasil (2016). APPLICATION OF GEOGRAPHIC INFORMATION SYSTEMS IN CRISIS MANAGEMENT, Management and Economics, National Military University, VelikoTarnovo, Bulgaria, REVISTA ACADEMIEI FORŢELOR TERESTRE NR. 2 (82).

Bundy, J., Pfarrer, M. D., Short, C. E.; Coombs, W. T. (2017). "Crises and crisis management: Integration, interpretation, and research development". Journal of Management.43 (6): 1661-1692. doi:10.1177/0149206316680030.

Shrivastava, P. Mitroff, I.I., Miller, D. and A. Miglani, (1988)." Understanding industrial crises".Journal of Management Studies, 25, 4, 285-304.

ASIS International (2009). "Organizational Resilience: Security, Preparedness, and Continuity Management Systems-Requirements with Guidance for Use, ASIS SPC.1-2009, American National Standard".

Eeger, M. W., Sellnow, T. L., Ulmer, R. R. (1998). "Communication, organization and crisis".Communication Yearbook.21: 231-275.

Venette, S. J. (2003). Risk communication in a High Reliability Organization: APHIS PPQ's inclusion of risk in decision making. Ann Arbor, MI: UMI Proquest Information and Learning.

Coombs, W. T. (1999). Ongoing crisis communication: Planning, managing, and responding. Thousand Oaks, CA: Sage.

Coombs, W. T. (1999). Ongoing crisis communication: Planning, managing, and responding. Thousand Oaks, CA: Sage. 
Lerbinger, O. (1997). The crisis manager: Facing risk and responsibility. Mahwah, NJ: Erlbaum. Johnson, Russ (2000). "GIS Technology for Disasters and Emergency Management"An ESRI White Paper,

Valenzuela, Nora M. (2008). Call center management, Applications Bureau, T.S. Manager, Riverside County Information Technology.

Copyright ( 2022 Dr. Taha Alfadul Taha Ali, AJRSP. This is an Open-Access Article Distributed under the Terms of the Creative Commons Attribution License (CC BY NC) Doi: https://doi.org/10.52132/Ajrsp.e.2022.35.4 